\title{
Lean Six Sigma for Quality and Performance Improvement of POH Process of Wagon Wheel CTRB
}

\author{
Tafadzwa Majoni, Prof. Prashant Tomar
}

Department of Mechanical Engineering, Parul Institute of Technology, Parul University Vadodara, Gujarat, India

\section{ABSTRACT}

Due to high competition in present world, every end user of a product demand their products to be delivered to them on time with good quality. Hence it is an objective of every industry to satisfy their customer requirements. In the long run, this can be achieved by continuous and constant process improvements. Lean Six Sigma is an overall quality improvement approach combining and capitalizing the strengths of Six Sigma and Lean Management improvement programs. In CTRB periodic overhaul, several process steps and workplaces are required for the job, the movement of inventory between the workplaces can be very time consuming unless it is suitably planned. The major areas that need great attention in this system are WIP (work in process), Takt time and process variability. In this study, focus is on the application of lean tools and techniques with their principles coupled with six sigma DMAIC methodology. The objective of this study is to identify the best possible tools and techniques to tackle premature failure of CTRBs whilst in service due to early presence of defects which are closely associated to the $\mathrm{POH}$ process. It also discusses the methodology generally adopted, tools and techniques used and benefits obtained. By mapping current state of the POH process and takt time, future state improvement can be done in order to reduce cycle time using Lean tools such as Poke-Yoke, Jidoka, 5S, SMED.

Keywords : Periodic Overhaul (POH), Cartridge Tapered Roller Bearings (CTRBs), DMAIC, Lean, Six Sigma

\section{INTRODUCTION}

Today, organisations strive for an improved level of process capability and manufacturing quality to achieve the bottom-line objectives of generating a profitable margin and sustainable competitiveness and share in the market. Lean Six Sigma is a quality improvement strategy that helps companies achieve these results. The main portion of this work will be dedicated to a case study analysis of the Periodic Overhaul $(\mathrm{POH})$ process at PratapNagar Railway Wheel and CTRB workshop. Based on a variety of literature and case study review, a Lean Six Sigma model will be developed and implemented at the facility.
To satisfy a growing demand and expectation from customers while coping with increasing product complexity and limited resources, organisations must improve on a continuous basis. As products become more complex, the number of components at the sub-assembly level becomes increasingly large, leading to a higher probability of defective assembly; as a result, there is a drive for superior component quality. Moreover, processes need to have a greater capacity and efficiency to provide a greater throughput to meet requirement.

This project focuses on the approach and application of the Lean Six Sigma methodology. Time has been devoted on literature review and studying a variety 
of cases to develop a thorough understanding of the methodology. The knowledge acquired has been applied continuously throughout the course for the work

\section{BACKGROUND}

PratapNagar railway workshop is the first state owned railway by ruler of Vadodara and pioneer to lay the first NG railway line between Dabhoi to Miyagaon in 1963. It was then materialized in 1973 when the complete track formation was upgraded. The foundation stone of PratapNagar workshop was laid by his highness Lord Chelmsford, Viceroy and Governor General of India on 25th March 1919.the workshop started in 1922.The workshop is currently being used for repairing and overhaul of coaches and wagons. PratapNagar Workshop consists of eight workshops. In the Wheel CTRB (Cartridge Tapper Roller Bearings) repair shop, $\mathrm{POH}$ (Periodic Overhaul) of High Precision E-Type CTRBs for CASNUB 22 HS bogies takes place. Cast Steel CASNUB 22HS-bogie is a type of railway bogie commonly used in freight stock/ wagons.

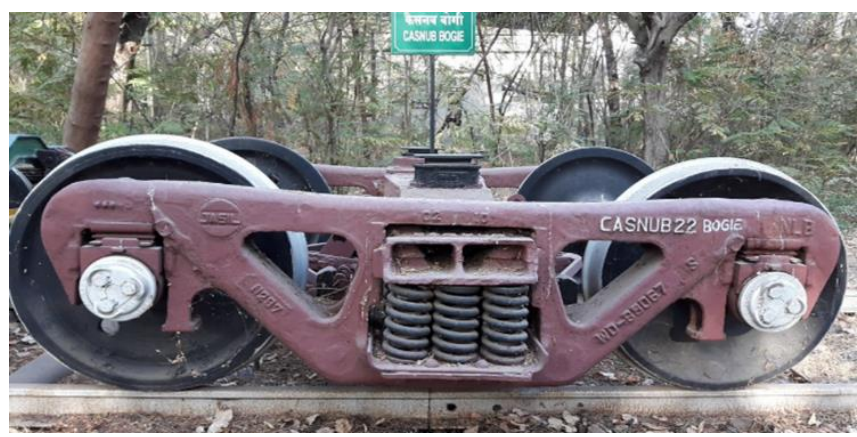

Figure 1 : CASNUB 22HS-Bogie

The main function of CTRB is to support axial and radial forces. The inner and outer ring raceways are segments of cones, the rollers are tapered so that the conical surfaces of the raceways, and the roller axes, if projected, would all meet at a common point on the main axis of the bearing. This geometry makes the motion of the cones remain coaxial resulting with no sliding motion between the raceways and the OD of the rollers. Pairs of tapered roller bearings are used in wagon wheel bearings where they must cope simultaneously with large vertical and horizontal forces. Tapered roller bearings are commonly used for moderate speed, heavy duty applications where durability is required.

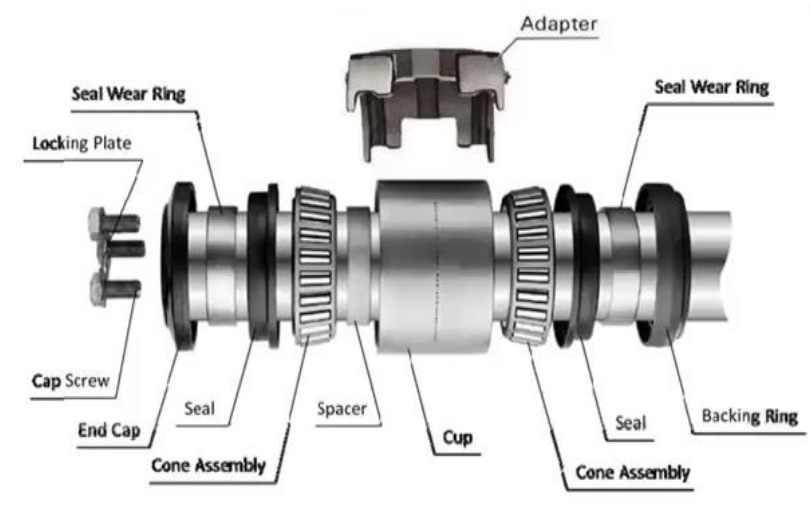

Figure 2 : EXPANDED VIEW OF CTRB

The components of CTRB unit are first dismantled in the dismantling unit. Due to long exposure to the environment and working conditions, grease gets hardened. First the unit is dipped in Kerosene oil to soften the grease. Stripping off of softened grease is done through centrifugal action by a Centrifugal Grease Purging (CPG) machine. Final cleaning is done in a tank where the bearing is subjected to kerosene oil and compressed air jet. When clean the components are inspected, checking for some defects. Defective bearings are rejected and the rest are passed on to greasing and assembly where each cone is filled with grease. Under normal circumstances, the predicted fatigue life of CTRBs is 25 years according to NBC Bearings which is the major supplier of bearings to Western Indian Railways (WIR). However, they are often condemned prematurely due to avoidable mistakes in the over hauling process. Accurate determination of the causes of bearing premature rejection must be done to make suitable recommendations for eliminating the cause. In contrast to fatigue life, this premature failure could be caused by incorrect fitting, improper mounting, improper handling, poor lubrication etc. 


\section{PROBLEM STATEMENT}

In a 12 week period from August to October 2018, 553 CTRBs were condemned before their set life span. $25 \%$ of the bearings were prematurely rejected hence affecting WIR operations as a projected 2.4 Crore (US\$332 000) can be wasted annually.

\section{AIM}

To improve the quality and performance of the $\mathrm{POH}$ process of CTRB at PratapNagar Railway Wheel CTRB workshop using lean six sigma.

\section{OBJECTIVES}

- Identify and eliminate causes of premature rejection of CTRBs

- Optimise the performance and quality of the $\mathrm{POH}$ process of CTRB.

- Maintain the improved POH process of the Wheel CTRB workshop for sustainability.

\section{SCOPE}

Only investigate the effect of the $\mathrm{POH}$ process to the lifespan of CTRB hence:

- Only focus on the eight frequently occurring defects that are associated to the $\mathrm{POH}$ process.

- Some other defects that occur due to mechanical or chemical effects whilst the bearing is in service are beyond the scope of this study.

- What happens to the rejected bearings is beyond the scope of this study

\section{FINDINGS OF LITERATURE REVIEW}

The DMAIC coupled with Lean techniques can be employed to achieve the efficient use of resources and to minimize non-value added activities in the process. Combining and capitalizing the strengths of Six Sigma and Lean Management improvement programs. The overall objective being to continuously improve in order to satisfy a growing demand and expectation from customers while coping with increasing product complexity and limited resources. All in all, literature review revealed that Lean Six Sigma implementation can provide a breakthrough improvement in any industry, Railway Industry included.

\section{RESEARCH GAP}

LSS has been used for high quality and performance improvement in numerous industries. There is however no model to measure the success of LSS deployment. There is a need to design a model to measure the impact of LSS implementation on organizational overall performance. The researcher believes that the model will assist new adopters of LSS to anticipate and additionally examine the impact of LSS on their operational overall performance.

\section{METHODOLOGY}

\section{DEFINE PHASE}

Define is the first step and decide what is required to be done. It brings a good understanding to everybody the need of project, its impact and implementation procedure. It should be clear what we want to achieve at the end.

\section{Project Charter}

It is a contract between the project team and its sponsors. It created a shared understanding about the project and the project goal. It mentioned mission, problem statement, possible gains, constraints and assumptions. It also mentioned important persons, key dates during the project and the project status. The charter included reasons for undertaking the project, objectives and constraints of the project. 


\section{Value Stream Mapping (VSM)}

Because of unfamiliarity with the $\mathrm{POH}$ process at the start of the project, the researcher decided to apply the Value Stream Mapping (VSM) technique to map out the process and identify the main problems of the process. VSM proved to be particularly useful for obtaining a bigger picture of the $\mathrm{POH}$ process, it also revealed general problem areas associated with the process.

The VSM captured the entire process, beginning with the dismounting of the CTRBs from the wheels and ending with the mounting of the serviced CTRB on the wheels. The VSM illustrated the physical movement of inventory and information. A time study was done on the entire process and the process cycle time (C/T) and available time (AT) for each process step was derived and listed on the map. The process map was developed based on timing results and observations made on-site at the Wheel and CTRB Workshop facility. Interactions with the workers at the workshop also provided with valuable information.

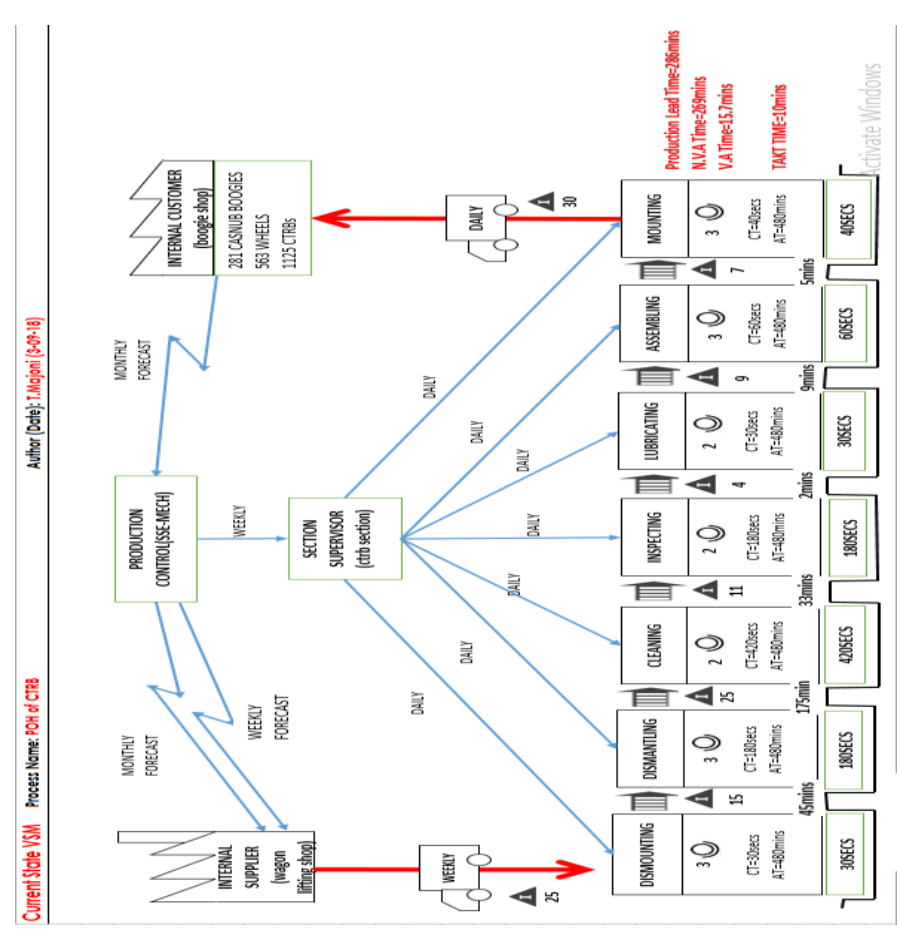

Figure 3 : Current Value Stream Map
A comprehensive understanding of the process was acquired upon completion of the VSM. In the process of developing the map, a list of findings, major areas of focus and concern were identified and summarized as follows:

- The process is running at a slower rate relative to the demand.

$$
\mathbf{T}_{c t}>\mathbf{T}_{k t}
$$

This leads to bottlenecks in the process, affecting the overall process performance.

- Due to the difference of Tkt and Tct there is a high build-up of Work-In-Progress (WIP).

- The non-value-added time of the POH process was found to be 4.4 hours, compared to 15.7 minutes of value-added operations.

These findings narrowed the focus for the researcher and helped to define and pinpoint the problems faced. Based on the observations of the uneven process flow and the high number of WIP level, the POH process was found to be inefficient, accounting for the large proportion of time dominated by non-value added activities. The inefficiency of the process and the unacceptable defects associated to this process imposed a negative effect on the company's objective of reducing all NVA activities (Integrated Management System Policy 2017 of PratapNagar Workshop). From this analysis, the objectives for the case were set clearly. The goals were to achieve an even, levelled-out flow as well as to improve the performance and quality of the $\mathrm{POH}$ process by eliminating non value adding activities that leads to CTRBs being condemned prematurely.

\section{MEASURE PHASE}

The development of the process map and the problem definition from the Define phase enabled the researcher to proceed to the Measure phase. The 
researcher identified from the Define phase that 25\% prematurely condemned bearings and process inefficiency were the major problem areas to focus on for the case. In the Measure phase, the goal is to validate and further develop the identified problem areas, as well as to gain a deeper understanding of the problems. To achieve this goal, the researcher continuously collected raw data and conducted further analysis.

\section{CTRB Rejection Data and Analysis}

To tackle the rejection rate problem, 12 weeks of yield-defect figures for the CTRBs were collected. After a thorough examination of the data, the researcher compiled an overall yield-defect graph and the defect breakdown Pareto chart for the $\mathrm{POH}$ process, as shown in Fig 4 and 5 respectively. The poor yield and the high rejection rate as indicated by the high DPMO gave an indication of the incapability and ineffectiveness of $\mathrm{POH}$ of CTRBs.

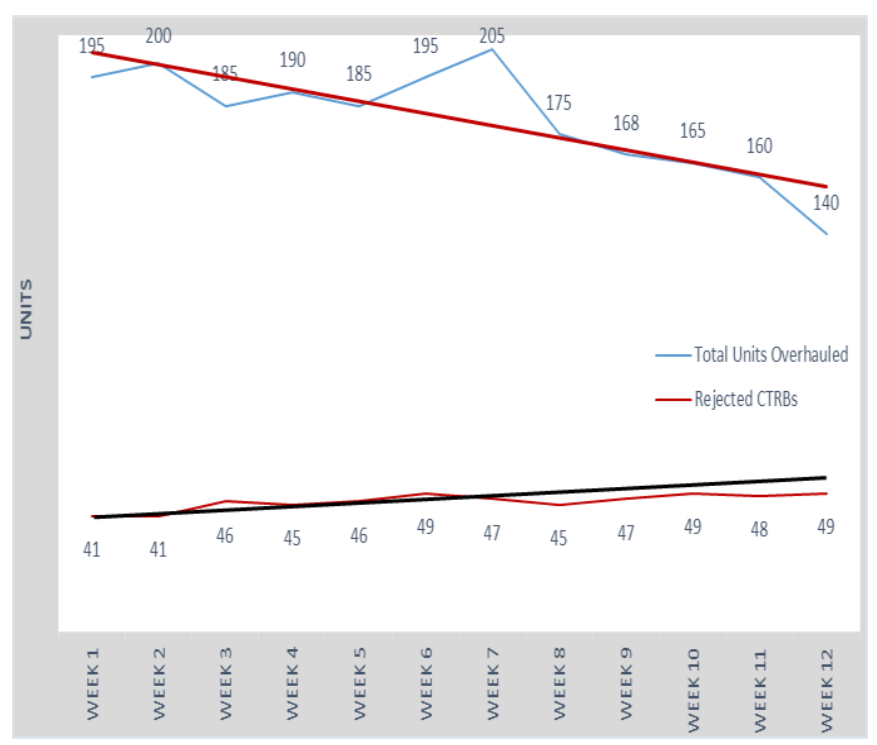

Figure 4 : Overall $\mathrm{POH}$ process Yield-Defect graph

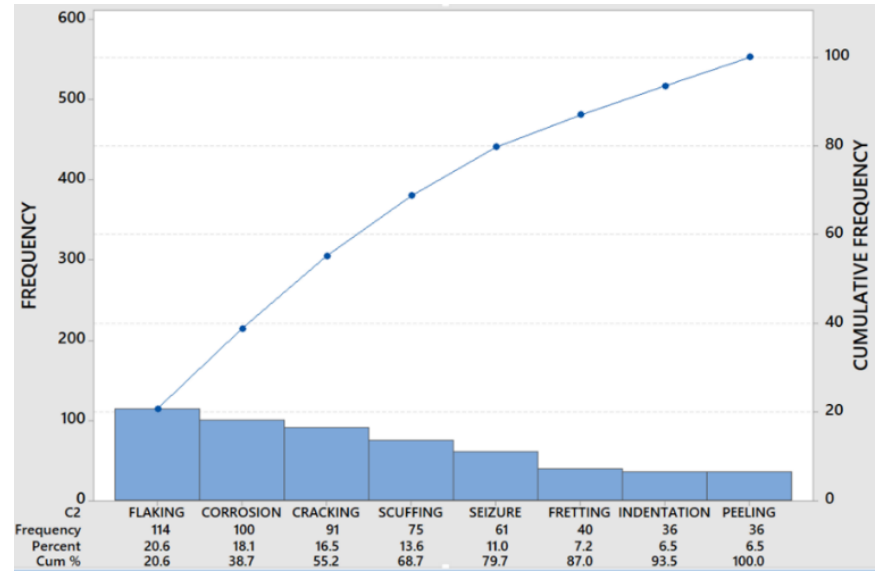

Figure 5 : defective chart for rejected CTRBs

Based on the Pareto chart, $55.2 \%$ of the condemned bearings were due to flaking, corrosion and cracking. These are the most frequently occurring defects that result in condemnation of the bearings, therefore in consultation with the Management it is agreed upon to apply Lean techniques using Six Sigma to eliminate these defects.

\section{Data Compilation of CTRB components wise}

Of the components the most critical components are the cup, cone assembly and the spacer ring. CTRB component wise data was collected to identify components which showed the highest frequency of being defective resulting in rejection of the bearing. The chart showed that $83 \%$ of the condemned bearings in the period were due to defective cup, spacer ring and cone assembly. This is not by coincidence since flaking, corrosion and cracking $(55.2 \%$ of the defects) directly attack these components. 


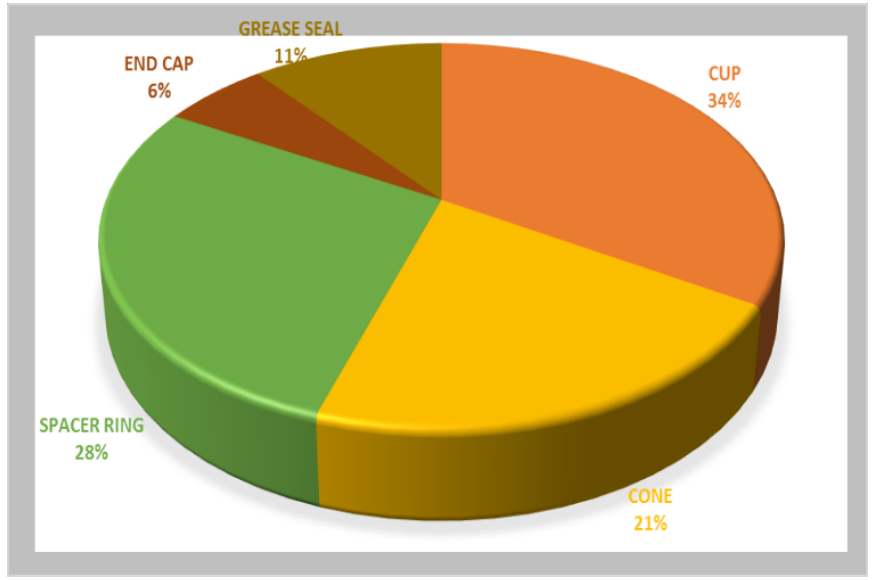

Figure 6 : CTRB Component Wise Cumulative Rejection

\section{Sigma Level Calculation}

Sigma level calculation is important to understand capability of $\mathrm{POH}$ process. Theoretically, the higher the sigma level the better is the performance. The six sigma level means 3.4 defects per million opportunities. The data collected in this project is discrete data therefore sigma level calculated is using DPMO method.

$$
\begin{array}{r}
D P M O=\frac{553 \times 1000000}{8 \times 2160} \\
=\mathbf{3 2 0 0 2 . 3 1}
\end{array}
$$

Current Sigma Level (DC Montgomery $6^{\text {th }}$ edition):

$$
\begin{aligned}
& \sigma=0.8406+(\sqrt{(29.37-2.221 x \ln [D P M O]})) \\
& =0.8406+(\sqrt{(29.37-2.221 x \ln [32002.31])}) \\
& =3.36 \\
& \approx 3.4
\end{aligned}
$$

The Integrated Management System Policy (IMSP 2017) of PratapNagar Workshop emphasise the need for continuous improvement and the need for process capability for sustainability. Therefore even a slight increase in sigma level is a welcome change for WIR.

\section{ANALYSE PHASE}

The objective is to identify the root cause of $\mathrm{POH}$ process variation based on information and data collected in Measure Phase. Additional data is also collected to find out cause of the problem. The data is analysed to check if there are consistent with the problem definition and also to identify the root cause. Three components of the CTRB namely Cup, Cone Assembly and Spacer ring; three types of defects namely Flaking, Corrosion and Cracking are considered for further study to arrive at root cause.

\section{Material Analysis of CTRBs Critical Components}

Primarily, high carbon chromium steel is used for the spacer rings and rolling elements. NBC bearings are of SUJ2 class of non stainless steel. The chemical composition of the SUJ2 is approximately the same as that of AISI 52100. AISI 52100 bearing steel is a high carbon, chromium containing low alloy steel. AISI 52100 bearing steel is one kind of special steel with features of high wear resistance and rolling fatigue strength etc.

\begin{tabular}{|c|c|c|c|c|c|c|c|}
\hline ELEMENT & $\mathrm{Fe}$ & $\mathrm{Cr}$ & $\mathrm{C}$ & $\mathrm{Mn}$ & $\mathrm{Si}$ & $\mathrm{S}$ & $\mathrm{P}$ \\
\hline $\begin{array}{c}\text { CONTENT/ } \\
\%\end{array}$ & $96.5-97.3$ & $1.3-1.6$ & $0.98-1.1$ & $0.25-$ & $0.15-0.3$ & $\leq 0.025$ & $\leq 0.025$ \\
& & & & 0.45 & & & \\
\hline
\end{tabular}

Figure 7 : AISI 52100 Chemical Composition

The cup is forged, rolled and machined from bearing quality case hardened steel. NBC bearings uses AISI 8620 to make the cup component of the CTRB. AISI 8620 alloy steel is flexible during hardening treatments thus enabling improvement of case/core properties

\begin{tabular}{|c|c|c|c|c|c|c|c|c|c|}
\hline ELEMENT & $\mathrm{Fe}$ & $\mathrm{Cr}$ & $\mathrm{C}$ & $\mathrm{Mn}$ & $\mathrm{Si}$ & $\mathrm{S}$ & $\mathrm{P}$ & $\mathrm{Mo}$ & $\mathrm{Ni}$ \\
\hline CONTENT/\% & $96.8-$ & $0.4-$ & $0.18-$ & $0.7-$ & $0.15-$ & $\leq 0.004$ & $\leq 0.035$ & $0.15-$ & $0.4-$ \\
& 98 & 0.6 & 0.23 & 0.9 & 0.35 & & & 0.35 & 0.7 \\
\hline
\end{tabular}

Figure 8 : AISI 8620 Chemical Composition

$\checkmark$ AISI 52100 stainless steel resist corrosion twice as much as many grades of steel alloys. Hence it can 
be concluded that the Spacer Ring and Cone Assembly are not prone to oxidation.

$\checkmark$ AISI 8620 can be oxidised due to its relatively low content of Cr. Hence we can conclude that the Cup is relatively more prone to oxidation.

All in all, the cone assembly and spacer ring are affected mainly by flaking and cracking whereas the cup is affected by corrosion, flaking and cracking.

\section{POH Process Stability}

Control chart is one of the most widely-used tools in the industry for providing an on-line processmonitoring mechanism. As a graphical display, the control chart shows the occurrences of process variability and instability. A specific type of attribute control chart called the $\mathrm{p}$-chart is employed in evaluating the stability of the process. Constructed with the collected yield-defect data for CTRBs

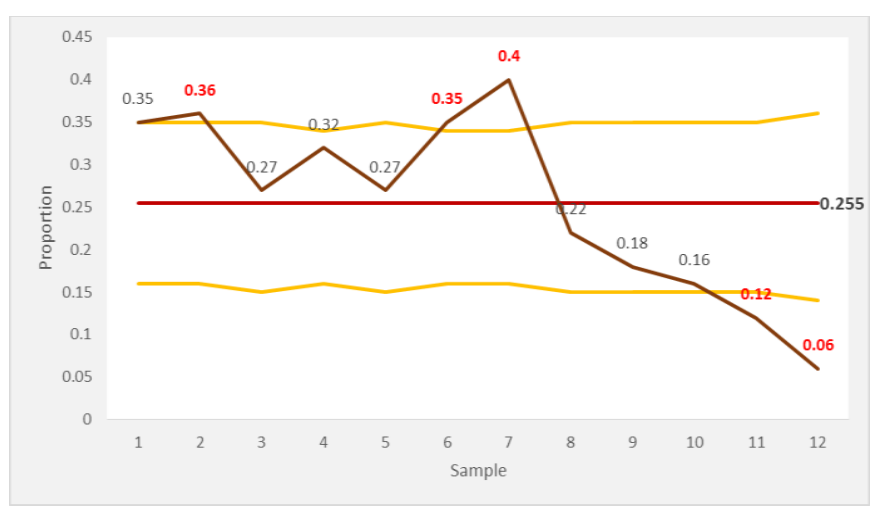

Figure $9: \mathrm{p}$-chart for rejected CTRBs

From the Control Chart, the average proportion of CTRBs which are rejected prematurely is 0.255 . In other words, it is $25.5 \%$ of the total bearings that undergo $\mathrm{POH}$ process. Highlighted points fell outside of the $3 \sigma$ limits hence the process is unstable and is out of statistical control.

\section{Process Failure Mode Effect Analysis (PFMEA)}

When engineers at PratapNagar workshop planned the $\mathrm{POH}$ process of CTRBs they envisioned a process which is free of errors due to either chance or assignable causes. Unfortunately, errors and especially errors propagated when there is involvement of humans can be quiet catastrophic and costly. PFMEA is a structured analytical tool used in this study to analyse the $\mathrm{POH}$ Process. This is achieved by analysing each process step to identify risks and possible errors from many different sources. In order to achieve the objective of this study it is important to identify errors and their effects for each process step as early as possible.

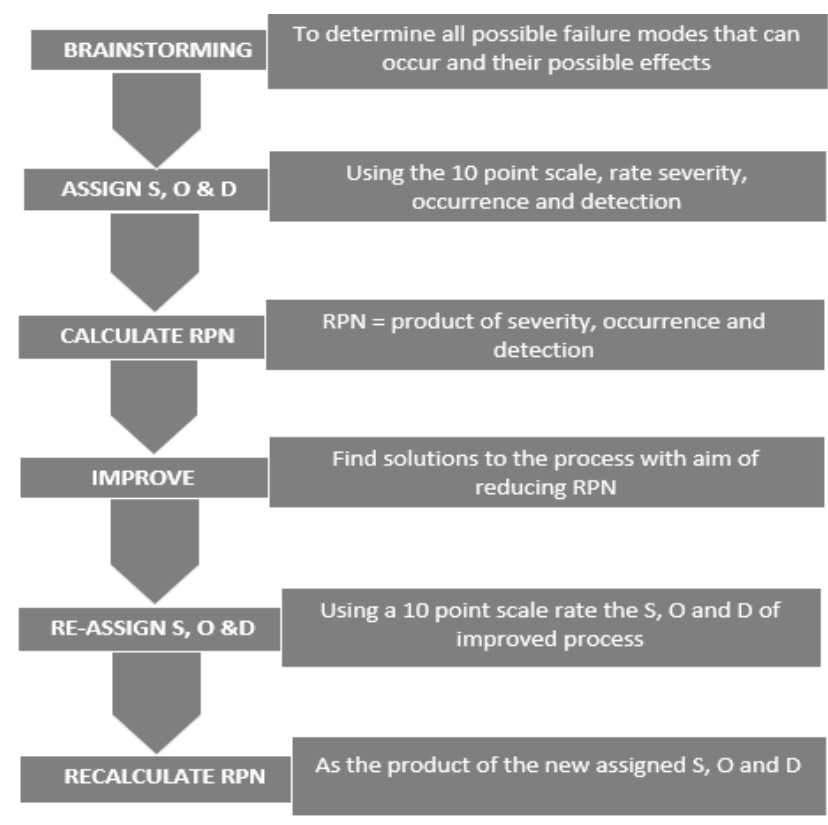

\section{Figure 10: PFMEA Methodology}

\section{IMPROVE PHASE}

In analysis phase the reasons of premature condemnation of CTRBs due to flaking, cracking and corrosion and also the reasons for process variability and inefficiency were identified. The root causes leading to poor quality and performance of the $\mathrm{POH}$ process were identified. And thı

- Improper Handling

- Entry of Moisture

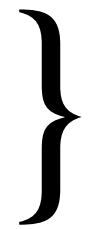

HOUSE

- Poor storage KEEPING

- Contamination

- Excessive mounting/assembly load

- Imbalanced work flow due to high Tct 
In improvement phase solutions are identified and implemented with the help of lean tools.

\section{$5 s$}

One of the most powerful Lean Tools and a cornerstone of any successful implementation. Lean tool for organising workplace in a clean, efficient and safe manner to enhance productivity, visual management and to ensure the introduction of standardised working resulting in minimised errors in the process. $5 \mathrm{~S}$ is split into 5 phases, each named after a different Japanese term beginning with the letter " $\mathrm{S}$ " i.e.

SEIRI Sort - Separating of the essential from the nonessential items.

SEITON Straighten - Organizing the essential materials a designated place.

SEISO Sweep - Cleaning the work area.

SEIKETSU Standardise - Establishing a system to maintain and make $5 \mathrm{~S}$ a habit.

SHITSUKE Sustain - Establishing a safe and sanitary work environment.

\section{Step 1: Seiri (sort)}

In this step the team organised and eliminated unnecessary items within the Workshop. This had to do with JIT, "just what is needed, in the quantity needed, only when needed". The programme ran under the name "Red Tag Campaign (RTC)" whereby tags were placed on items not required in the shop floor. The RTC is a strategy employed to identify potentially unnecessary items in the shop floor, evaluate their usefulness and treat them appropriately

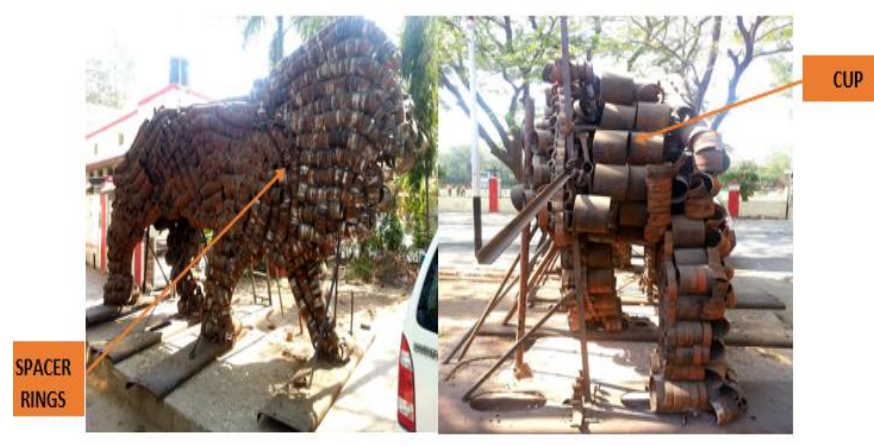

Figure 11 : Disposed CTRB components

\section{Step 2: Seiton (set in order)}

Seiton means setting in order the necessary elements so that they are easy to find and use by anyone within the shop floor. The concept of setting in order can be summarised in one sentence as "a place for everything and everything in its place"

Focus: Dedicated permanent storage areas for all necessary equipment and items in the shop floor.

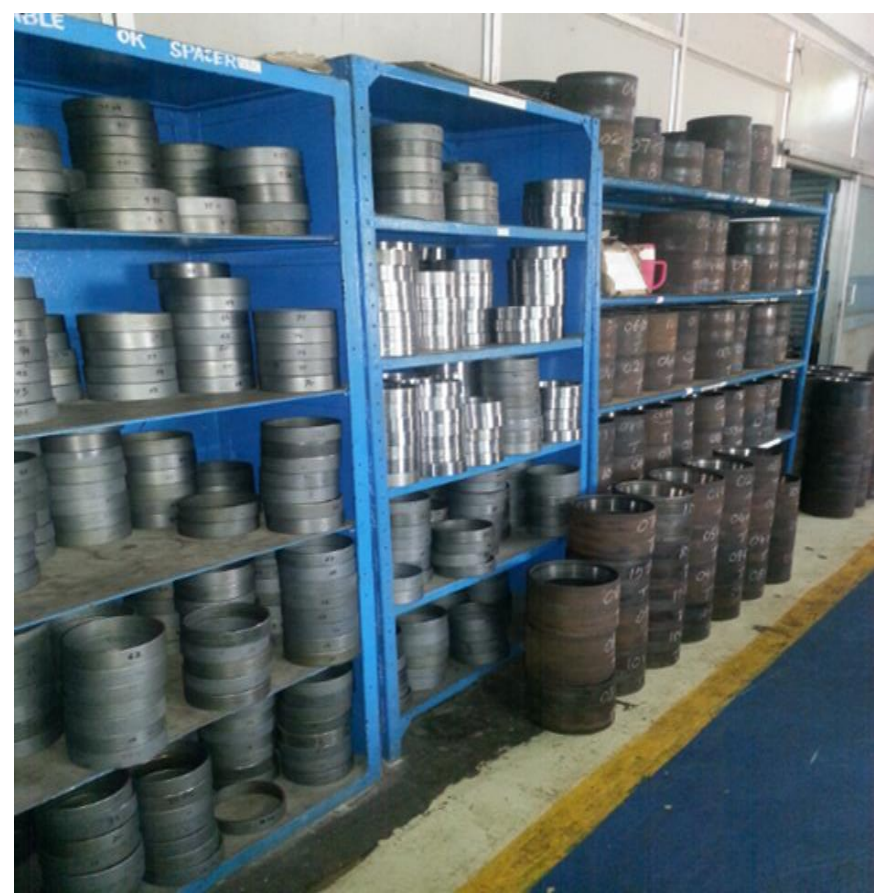

Figure 12 : CTRB Components set in order

\section{Step 3: Seiso (sweep)}

Involves cleaning everything in the shop floor, keeping it clean daily and using cleaning to inspect the workplace and equipment for malfunctions, 
leakages etc. Accumulation of dust or file metal shavings can easily lead to contamination of bearing components leading to defects, faulty equipment and even accidents. The causes can be eliminated by appropriate cleaning on a daily basis.

Focus: Maintain a clean and safe working conditions thus letting people be responsible for the equipment they are using

\section{Step 4: Seiketsu (standardise)}

No activity would be performed per say, this stage does not refer to an activity, but rather a state or condition. Seiketsu would consist of building a strong set of procedures to maintain the first 3S. In fact, it is the state that exists when the first $3 \mathrm{~S}$ are properly maintained. When implementing Seiketsu the team made sure to follow the three steps as follows:

- Decide who is in charge of maintaining the needed conditions to maintain the first $3 \mathrm{~S}$

- Avoid setbacks by means of integrating daily maintenance.

- Check the level of maintenance

Focus: Establish standardised 5S system

When the same problem occurs again and again, it's time to go to the next level: prevention

\section{Step 5: Shitsuke (sustain)}

Basically an extension of Seiketsu (standardise). Shitsuke (sustain) means turning all activities already carried out in previous steps into a habit, that is the fact of maintaining the correct procedures within the shop floor.

Focus: Formalise 5S system work area policy

\section{S Conclusion}

When fully implemented, 5S will help maintain a clean work area leading to reduced contamination, correct ambience to eliminate entry of moisture in grease and bearing components, enable proper storage and handling of all equipment used in the $\mathrm{POH}$ process. It will also create positive impression on customer (boogie shop), and increase efficiency in the CTRB Workshop. Not only will employees feel better about where they work, the effect on continuous improvement (IMSP 2017) can lead to less waste, better quality and faster lead times.

\section{POKA-YOKE}

Poka Yoke is a simple technique that is normally a simple and often inexpensive device that prevents defects from being made or highlights a defect so that it is not passed to the next operation. Poka yoke is to be implemented so that there is no excessive loading when assembling and mounting CTRBs on the wheel axle.

The bearing assembly is pushed onto the bearing journal by a hydraulic press. Normally 12-15 tonne/square inch pressure is required to push the bearing to its position. An assembled CTRB weighs $32 \mathrm{~kg}$, to prevent misalignment a pilot sleeve is be fastened to the end of the axle to keep the bearing parts together and protect them from damage. The pilot sleeve is removed when the bearing is in its position. If excessive force is applied on the bearing the bearing will be forced to the journal collar and this will lead to premature cracking of the bearing components.

To prevent the bearing to be forced onto the journal collar before the hydraulic presser stops, the pilot sleeve is modified from its original form. 


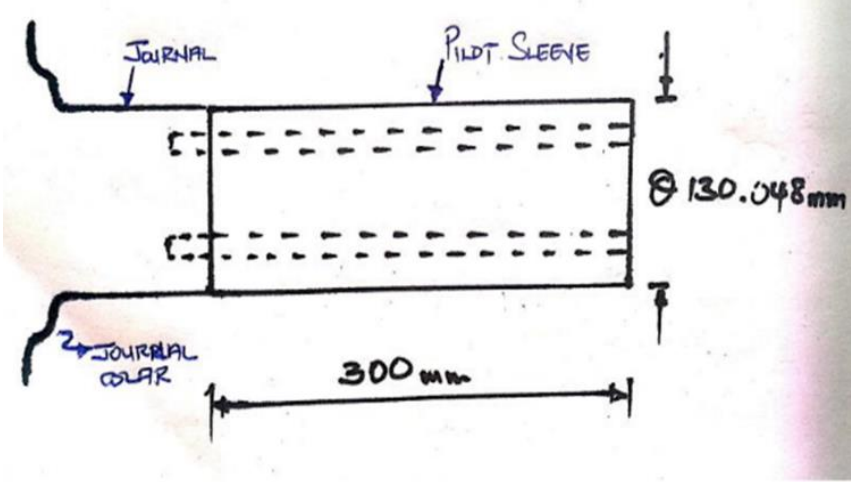

Figure 13 : Original form Pilot Sleeve

A $10 \mathrm{~mm}$ deep groove is milled on the surface of the sleeve and at the end of the groove a $20 \mathrm{~mm}$ blind hole is drilled. On the pushing tube which is part of the hydraulic press, a flexible $40 \mathrm{~mm}$ diameter pin is attached on a hinge such that it moves along the groove on the sleeve, figure 4.12. To stop the motion of the hydraulic press, the hinged pin falls into the drilled hole at the end of the groove. This will alert the operator to retract the hydraulic presser and prevent excessively loading the bearing against the journal collar.

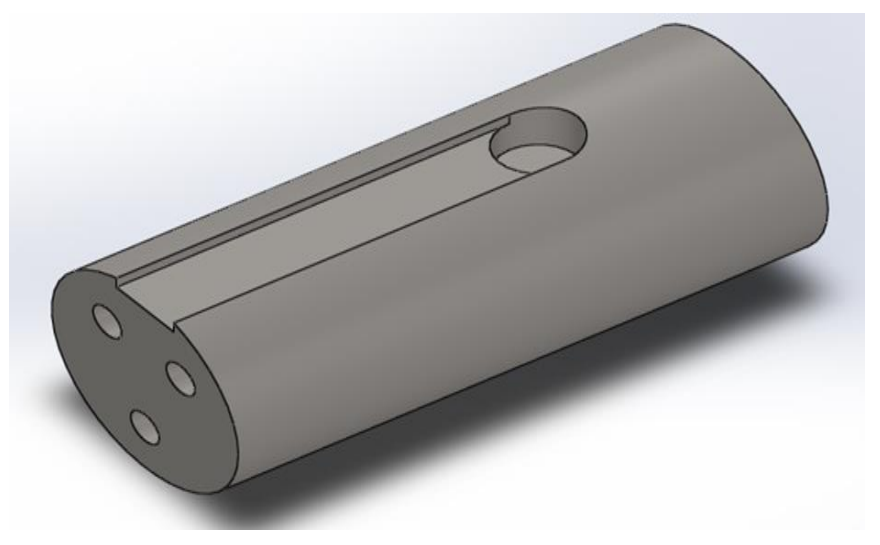

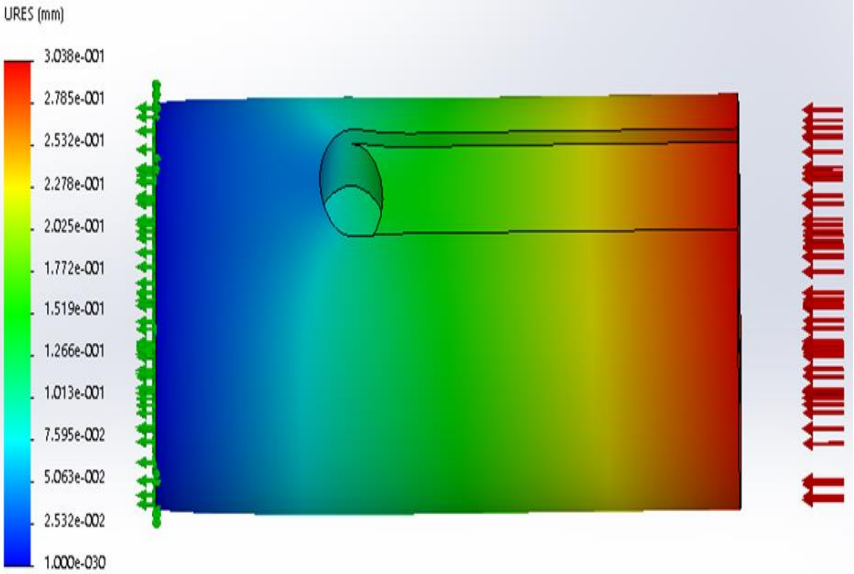

Figure 14 : Modified Pilot Sleeve

With the small modification on the pilot sleeve, the CTRB will be protected from excessive force which pushes it on to the journal collar. This will eliminate premature cracking of the bearing due to excessive loading on mounting. This motion stop Poka-Yoke will take physical action to prevent excessive mounting load hence it is a control Poka-Yoke.

\section{SINGLE MINUTE EXCHANGE of DIE (SMED)}

SMED is a lean tool which is used to reduce setup time and provide quick changeover. The main aim of SMED is to reduce the time wasted in changeover steps by performing some activities while the process is running, and to integrate and reduce the time required to perform internal tasks. The SMED places the tasks into two categories which are internal and external activities. External activities being those activities performed while the process is running. The internal activities on the other hand are activities which are done while the process is not running.

The $\mathrm{POH}$ process is running at a slower rate relative to the demand, $\mathrm{T}_{\mathrm{ct}}>\mathrm{T}_{\mathrm{kt}}$. This is resulting in bottlenecks in the process affecting process performance, leading to high WIP. The main reason observed why there is such a huge time discrepancy is because of change over time. High change overs are 
observed in Dismantling, Cleaning and Mounting steps of the $\mathrm{POH}$ process. In the mounting step, change over occurs when switching from axle to axle and also when switching from left wheel to the right wheel of the same axle. To improve the changeover time SMED is employed. The SMED is going to follow the framework:

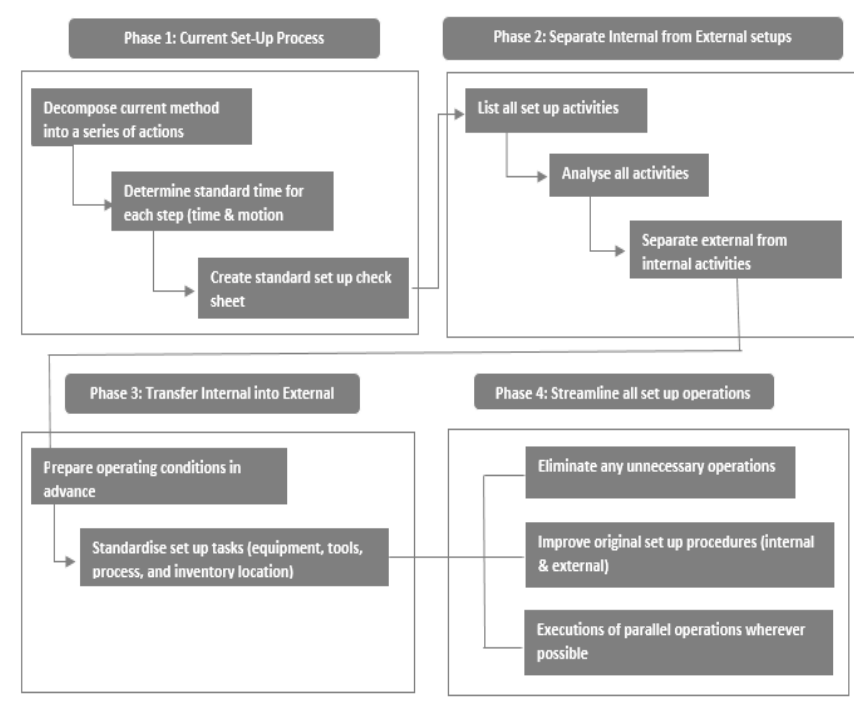

Figure 15 : SMED Framework

\begin{tabular}{|l|l|c|c|c|}
\hline \multicolumn{1}{|c|}{$\begin{array}{c}\text { Eliminated } \\
\text { Task }\end{array}$} & \multicolumn{1}{|c|}{ Reason } & $\begin{array}{c}\text { Time/s } \\
\text { saved }\end{array}$ & Frequency/day & $\begin{array}{c}\text { Total } \\
\text { Time } \\
\text { saved/s }\end{array}$ \\
\hline $\begin{array}{l}\text { Creating space to } \\
\text { put the bearing } \\
\text { units }\end{array}$ & $\begin{array}{l}\text { Due to sustainable } 5 \text { S in the shop floor, } \\
\text { the work space is always clear. }\end{array}$ & 39 & 3 & 117 \\
\hline $\begin{array}{l}\text { Movement to } \\
\text { collect } \\
\text { dismantling tools }\end{array}$ & $\begin{array}{l}\text { All frequently used tools are placed } \\
\text { within arm's reach in the shop floor, }\end{array}$ & 30 & 3 & 90 \\
\hline $\begin{array}{l}\text { Loosen the clamp } \\
\text { Use a bench vice that can hold the bearing } \\
\text { unit facing sideways rather than the } \\
\text { clamp which holds the unit facing } \\
\text { upwards }\end{array}$ & 5 & 30 & 150 \\
\hline $\begin{array}{l}\text { Secure } \\
\text { bearing } \\
\text { upside down }\end{array}$ & $\begin{array}{l}\text { Use a bench vice that can hold the bearing } \\
\text { unit facing sideways rather than the } \\
\text { clamp which holds the unit facing } \\
\text { upwards }\end{array}$ & 7 & 30 & 150 \\
\cline { 2 - 6 } & \begin{tabular}{l} 
TOTAL TIME SAVED \\
\cline { 2 - 5 }
\end{tabular} & & & \\
\hline
\end{tabular}

Figure 16: Dismantling Eliminated Activities

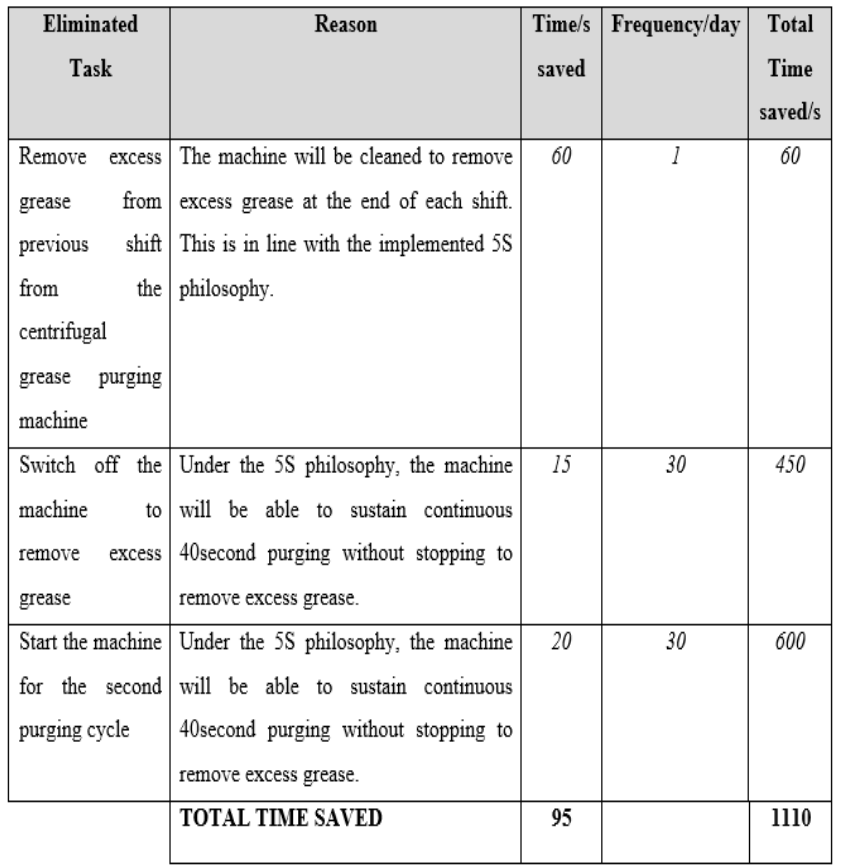

Figure 17 : Cleaning Eliminated Activities

\begin{tabular}{|l|l|c|c|c|}
\hline \multicolumn{1}{|c|}{$\begin{array}{c}\text { Eliminated } \\
\text { Task }\end{array}$} & $\begin{array}{c}\text { Reason } \\
\text { saved }\end{array}$ & Frequency/day & $\begin{array}{c}\text { Total } \\
\text { Time } \\
\text { saved/s }\end{array}$ \\
\hline $\begin{array}{l}\text { Collecting of all } \\
\text { equipment and } \\
\text { material needed } \\
\text { for mounting }\end{array}$ & $\begin{array}{l}\text { All frequently used tools are placed } \\
\text { within arm's reach in the shop floor. }\end{array}$ & 47 & 2 & 94 \\
\hline $\begin{array}{l}\text { Check the oil } \\
\text { level of the } \\
\text { hydraulic presser }\end{array}$ & $\begin{array}{l}\text { The oil will be checked daily after each } \\
\text { shift. }\end{array}$ & 4 & 1 & 4 \\
\cline { 2 - 5 } & TOTAL TIME SAVED & $5 l$ & & 98 \\
\cline { 2 - 5 }
\end{tabular}

Figure 18 : Mounting Eliminated Activities

\section{SMED Conclusion}

\begin{tabular}{|c|c|c|c|}
\hline & Before SMED & After SMED & Time save \\
\hline Total Cycle time/ shift & $437 \mathrm{mins}$ & $324.5 \mathrm{mins}$ & $112.5 \mathrm{mins}$ \\
& (7hrs) & (5hrs) & (2hrs) \\
\hline
\end{tabular}

The implementation of SMED saved 227 seconds from the initial 942 seconds (Chart 4.2). This has 
reduced $\mathrm{T}_{\mathrm{ct}}$ from 15.7 mins to 11 mins. All in all this new $\mathrm{T}_{\mathrm{ct}}$ is approx. 60 seconds more than $\mathrm{T}_{\mathrm{kt}}$ of 600 seconds.

$$
T_{c t} \approx T_{k t}
$$

\section{Improve Phase Recommendations}

\begin{tabular}{|c|c|c|c|c|}
\hline SN & COMPONENT & EFFECT & Root CAUSES & COUNTER MEASURE \\
\hline 1 & $\begin{array}{l}\text { Cone, Spacer } \\
\text { Ring, Cup }\end{array}$ & Flaking & $\begin{array}{c}\text { Contamination, } \\
\text { excessive mounting } \\
\text { load, inclined } \\
\text { mounting, eccentric } \\
\text { mounting, }\end{array}$ & $\begin{array}{l}\text {-Ensure a clean working environment by } \\
\text { implementing } 5 \mathrm{~S} \text {. } \\
\text {-Modify the pilot sleeve (POKA-YOKE) }\end{array}$ \\
\hline 2 & $\begin{array}{l}\text { Cone, Spacer } \\
\text { Ring, Cup }\end{array}$ & Cracking & $\begin{array}{c}\text { Excessive mounting } \\
\text { load }\end{array}$ & -Modify the pilot sleeve (POKA-YOKE) \\
\hline 3 & Cup & Corrosion & $\begin{array}{c}\text { Entry of moisture, } \\
\text { improper storage } \\
\text { conditions, improper } \\
\text { handling, }\end{array}$ & $\begin{array}{l}\text {-Ensure a clean working environment and culture by } \\
\text { implementing } 5 \mathrm{~S} \text {. } \\
\text {-PPC should always be worn in the shop floor } \\
\text { including hand gloves when handling CTRBs }\end{array}$ \\
\hline 4 & $\begin{array}{c}\text { Process } \\
\text { Inefficiency }\end{array}$ & High WIP & $\begin{array}{l}\text { Imbalanced work } \\
\text { flow, reduced } \\
\text { equipment run rate, } \\
\text { unnecessary } \\
\text { stoppages }\end{array}$ & $\begin{array}{l}\text {-Eliminate unnecessary activities to reduce process } \\
\text { set-up times by employing SMED coupled with } 5 \mathrm{~S} \text { for } \\
\text { clean working area }\end{array}$ \\
\hline
\end{tabular}

Figure 19 : recommended Solutions

\section{CONTROL PHASE}

Now the bigger question is, how are we going to sustain our improvements? Now that the process problems are fixed and improvements have been recommended, the team must ensure that the updated process maintains the gains. Focus is on creating a monitoring plan to continue measuring the success of the updated process and developing a response plan in case there is a dip in performance. Once in place the team hands over all these plans to the process owner for ongoing maintenance.

\section{Performance Monitoring}

There has been a significant increase in the number of units overhauled per shift. Previously, 30 bearings would undergo $\mathrm{POH}$ process per shift but now 39 bearings are overhauled per shift fig 20. However as expected, the condemned bearings are still as before i.e. $25 \%$. This is because the bearings overhauled now were once overhauled before improvements were made. This is however projected to reduce to $12 \%$ after a period of 24-36 months from February 2019. Fig 21 show the number of bearings condemned in March 2019 after some process improvements were made.

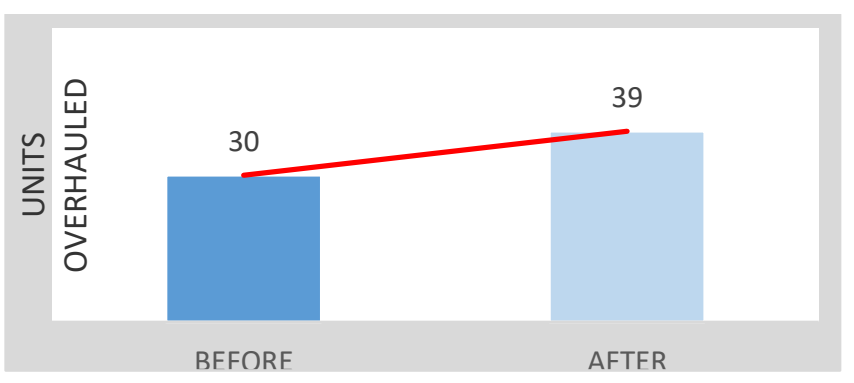

Figure 20 : CTRBs overhauled per shift

\begin{tabular}{|l|l|l|l|l|}
\hline DAY & WEEK & WEEK & WEEK & WEEK \\
\hline MON & 6 & $\mathbf{2}$ & $\mathbf{3}$ & $\mathbf{4}$ \\
\hline TUES & 10 & 11 & 14 & 7 \\
\hline WED & 10 & 13 & 12 & 9 \\
\hline THUR & 9 & 10 & - & 11 \\
\hline FRI & 12 & 12 & 13 & 10 \\
\hline SAT & 11 & 9 & 11 & 8 \\
\hline $\begin{array}{l}\text { TOTAL } \\
\text { rejected }\end{array}$ & 58 & 63 & 59 & 57 \\
\hline $\begin{array}{l}\text { TOTAL } \\
\text { overhauled }\end{array}$ & $\mathbf{2 4 7}$ & $\mathbf{2 4 4}$ & $\mathbf{2 1 1}$ & $\mathbf{2 4 4}$ \\
\hline \% Rejected & $\mathbf{2 3 . 4 8 \%}$ & $\mathbf{2 5 . 8 2 \%}$ & $\mathbf{2 7 . 9 6 \%}$ & $\mathbf{2 3 . 3 6 \%}$ \\
\hline
\end{tabular}

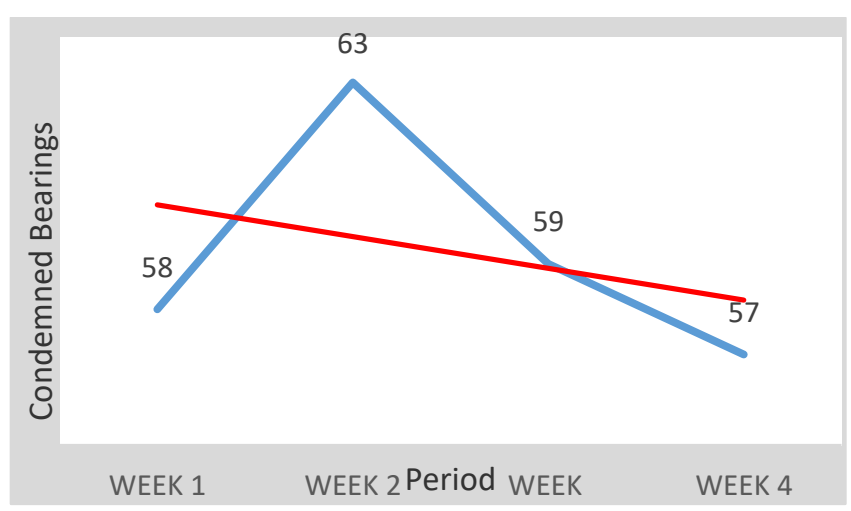

Figure 21 : Condemned bearings in March 2019

After this data collection, overall yield-defect graph for the $\mathrm{POH}$ process, as shown below was created. 
The trend lines are almost parallel relative to fig 4 mainly due to the increase in the number of units overhauled per shift.

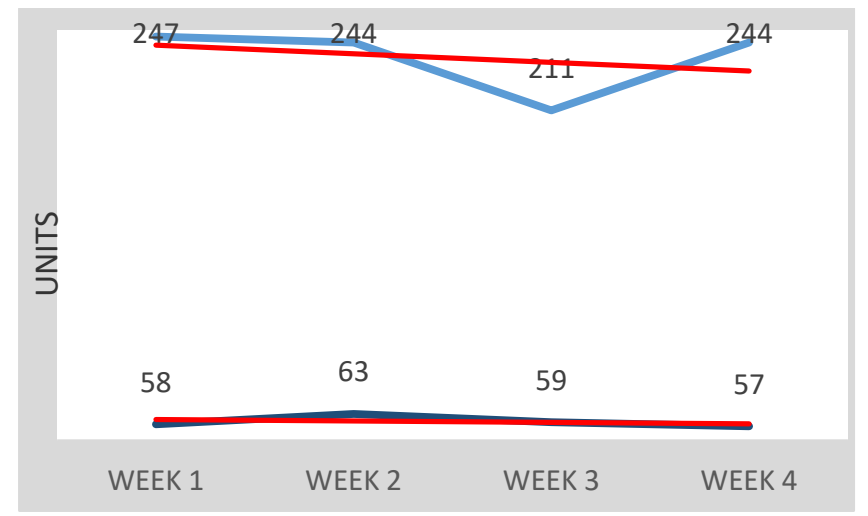

Figure 22 : Overall yield-defect graph for March 2019

Due to limited time to monitor the changes in the process, the changes in DPMO and sigma levels will be very small. The projection is that after 24-36 months from implementation the changes will be big

$$
\begin{array}{r}
D P M O=\frac{237 \times 1000000}{8 x 946} \\
=\mathbf{3 0 3 0 6}
\end{array}
$$

$$
\begin{aligned}
& \boldsymbol{\sigma}=0.8406
\end{aligned}
$$

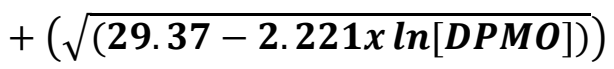

$$
\begin{aligned}
& =0.8406+ \\
& (\sqrt{(29.37-2.221 x \ln [30306])}) \\
& =3.48 \\
& \approx 3.5
\end{aligned}
$$

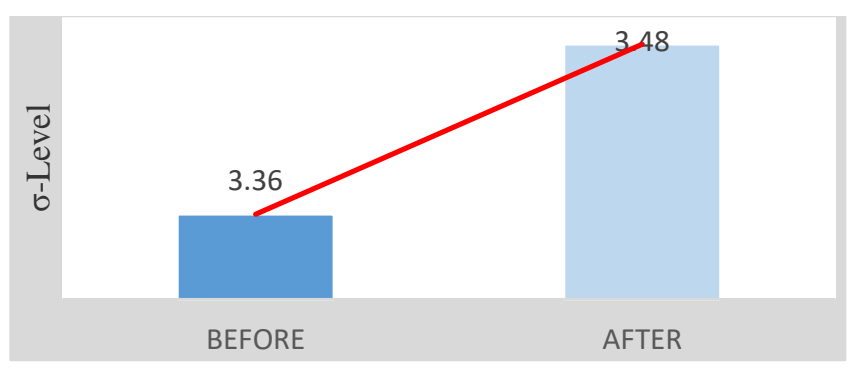

Figure 23 : Sigma Level Changes

DPMO has reduced by $5.3 \%$ which indicate that the performance of the $\mathrm{POH}$ process of CTRBs has improved. Percentage improvement of sigma level is $0.6 \%$. These percentages are relatively small because of some limitations already highlighted. Moreover some of the solutions are not yet implemented. Further increase in sigma level needs implementation of all recommended solutions.

\section{Control Plan}

Organisations are good at rallying around chronic problems and finding solutions. But the long term discipline in sustaining solutions is a totally different story, all too often a process will slowly return to its original state as the path of least resistance takes control. This is where control plans play a vital role in sustaining process improvements over the long run. A guide to continued monitoring of the process and the response plan for each of the measures being monitored. It describe the CTQ characteristics of the $\mathrm{POH}$ process. Through this system of monitoring and

\begin{tabular}{|c|c|c|c|c|c|c|}
\hline STEP & EQUIPMENT & CTQ & SPECS & SIZE & FREQ & RESPONSE \\
\hline DISMOUNTING & $\begin{array}{l}\text { Hyaraulic } \\
\text { extractor }\end{array}$ & time & $\begin{array}{l}<49.5 \min \\
\text { s/shift }\end{array}$ & $\begin{array}{l}\text { Daily } \\
\text { yield }\end{array}$ & $\begin{array}{l}\text { All } \\
\text { units }\end{array}$ & $\begin{array}{l}\text { With help of wagon lifting shop keep exact } \\
\text { records of reasons of step delays. }\end{array}$ \\
\hline DISMANTLING & Hyaraulic press & time & $\begin{array}{l}117 \text { mins } \\
\text { /shift }\end{array}$ & $\begin{array}{l}\text { Daily } \\
\text { yield }\end{array}$ & $\begin{array}{l}\text { All } \\
\text { units }\end{array}$ & $\begin{array}{l}\text { If delayed request for more personnel to } \\
\text { avoid WIP build-up. }\end{array}$ \\
\hline \multirow[t]{2}{*}{ CLEANING } & Kerosene tank & time & $\begin{array}{l}\text { <165mins } \\
\text { /shift }\end{array}$ & $\begin{array}{l}\text { Daily } \\
\text { yield }\end{array}$ & $\begin{array}{l}\text { All } \\
\text { units }\end{array}$ & Keep exact records of delays \\
\hline & CP Machine & time & & $\begin{array}{l}\text { Daily } \\
\text { yield }\end{array}$ & $\begin{array}{l}\text { All } \\
\text { units }\end{array}$ & $\begin{array}{l}\text { Keep records of delays and maintenance } \\
\text { especially of CP Machine }\end{array}$ \\
\hline LUBRICATION & Lubricating gun & time & $\begin{array}{l}<165 \mathrm{mins} \\
\text { /shift }\end{array}$ & $\begin{array}{l}\text { Daily } \\
\text { yield }\end{array}$ & $\begin{array}{l}\text { All } \\
\text { units }\end{array}$ & $\begin{array}{l}\text { If delayed, only lubricate what can be } \\
\text { assembled in that same shift }\end{array}$ \\
\hline ASSEMBLY & $\begin{array}{l}\text { Assembly } \\
\text { presser }\end{array}$ & time & $\begin{array}{l}<19.5 \min \\
\text { s/shift }\end{array}$ & $\begin{array}{l}\text { Daily } \\
\text { yield }\end{array}$ & $\begin{array}{l}\text { All } \\
\text { units }\end{array}$ & $\begin{array}{l}\text { Keep exact records of the reasons for } \\
\text { assembly delays if they occur }\end{array}$ \\
\hline MOUNTING & Hydraulic press & time & $\begin{array}{l}\text { <110mins } \\
\text { shift }\end{array}$ & $\begin{array}{l}\text { Daily } \\
\text { yield }\end{array}$ & $\begin{array}{l}\text { All } \\
\text { units }\end{array}$ & $\begin{array}{l}\text { To avoid WIP, get the daily demand from } \\
\text { boogie shop and keep exact records of } \\
\text { delays }\end{array}$ \\
\hline
\end{tabular}
control VOB and VOC will be met and the process variations will be reduced. This plan is not a replacement of detailed operator instructions in the form of work instruction or standard operating procedures.

Figure 24 : Control Plan

As mentioned, in this phase, performance monitoring after implementation of some recommended solutions was done in March 2019 i.e. for 4 weeks. 
Performance monitoring indicated that recommended solutions are effective and resulted in improvement if fully implemented. Therefore the recommended solutions were standardised and documented fig 24 . With this the dissertation study was closed.

\section{CONCLUSION}

The DMAIC approach can be followed to identify the causes of different industrial problems, measure the process capability, analyse the potential causes of demoted quality, implement improvements and control the process such that long-term improvements can be sustained. Lean tools and techniques can be employed to achieve the efficient use of resources and to minimize non-value added activities in the process. Combining and capitalizing the strengths of Six Sigma and Lean Management improvement programs. The overall objective being to continuously improve in order to satisfy a growing demand and expectation from customers while coping with increasing product complexity and limited resources.

All in all it can be concluded that the following can be achieved by implementing LSS:

- PROCESS CAPABILITY: the uniformity of the process

- SUSTAINABILITY: the economically sound processes that minimise negative environmental impacts whilst conserving energy and natural resources.

- COMPETITIVENESS - avoiding penalties for non-compliance products, lowering costs of production, increasing productivity, and consequently reduced amount of WIP

- CUSTOMER SATISFACTION - increased customer satisfaction due to increased timeliness and reduced lead time.
- EMPLOYEE MORALE- increased comfort and better organization, lack of overtime,

- DEMING'S 5TH POINT OF QUALITY: continuously improve the process of production to minimise waste and improve on productivity and efficiency.

- OTHER- the possibility of taking more orders during a prescribed period.

All in all, Lean Six Sigma implementation can provide a breakthrough improvement in any industry, Railway Industry included.

\section{REFERENCES}

\section{PAPERS}

[1] David Woo, Holly Wong, "An Application of Lean Six Sigma To Improve

The Assembly Operations At A Wireless Mobile Manufacturing Company", Procedia CIRP, Elsevier 44,157-162,2016

[2] Sri Indrawati, Muhammad Ridwansyah, "Manufacturing Continuous Improvement Using Lean Six Sigma: An Iron Ores Industry Case Application", Procedia Manufacturing, Elsivier 4 ( 2015 ) 528 - 534

[3] Adrian Pugna, "Using Six Sigma Methodology to Improve the Assembly Process in an Automotive Company", Procedia - Social and Behavioural Sciences, Elsivier 221 ( 2016 ) 308 $-316$

[4] Lubica Simanová, "Specific Proposal of the Application and Implementation Six Sigma in Selected Processes of the Furniture Manufacturing", Procedia Economics and Finance, Elsivier 34 ( 2015 ) 268 - 275

[5] Alexandra Tenera, "A Lean Six Sigma (LSS) project management improvement model", Procedia - Social and Behavioral Sciences, Elsivier 119 ( 2015 ) 912 - 920

[6] Lars Krogstie and Kristian Martinsena "Beyond Lean and Six Sigma; Cross-Collaborative Improvement of Tolerances and Process Variations - A Case Study" Procedia CIRP, 
Elsivier 7 ( 2016 ) $610-615$

[7] Salah A.M. Elmoselhy "Hybrid lean-agile manufacturing system technical facet, in automotive sector" Journal of Manufacturing Systems, Elsivier 32 (2015) 598- 619

[8] Brian W.Jacobsa "Performance effects of early and late Six Sigma adoptions", Journal of Operations Management, Elsivier 36(2015)244-257

[9] T.Costa, " Improve the extrusion process in tyre production using Six Sigma methodology", Procedia Manufacturing, Elsivier 13 (2017) 11041111

[10] Islam Moha and Hasibul, "Adoption of lean philosophy in car dismantling companies in Sweden," Procedia Manufacturing, Elsivier (2018) 620-627

[11] J. Oliveira, "Continuous Improvement through Lean Tools", Procedia Manufacturing, Elsivier 13 (2017) 1082-1089

[12] S.R.Devadasanc and C.Sugumarand "Enhancing effectiveness of Shell and Tube Heat Exchanger through Six Sigma DMAIC phases", Procedia Engineering, Elsivier 97 ( 2015 ) $2064-2071$

[13] V. K. Sukhwani "Quality Improvement by using Six Sigma DMAIC in an Industry" International Journal of Current Engineering and Technology (2016)

[14] Abdulaziz A “Application of Lean Six-Sigma Methodology to Reduce the Failure Rate of Valves at Oil Field" Proceedings of the World Congress on Engineering and Computer Science 2014 Vol II WCECS 2014, 22-24 October, 2014,

[15] D. Pavletic "Application of Six Sigma methodology for process design quality improvement" Journal of Materials Processing Technology, ,Elsevier,162,777-783(2015)

[16] Jeroen de Mast "An analysis of the Six Sigma DMAIC method from the perspective of problem solving" Int. Journal of Production Economics, Elsevier (2012)

[17] Eirin Lodgaarda and Jonas A. Ingvaldsena "Barriers to continuous improvement: perceptions of top managers, middle managers and workers" Procedia CIRP 411119 - 1124 (2016)

[18] Magdalena K. "Mirages of Lean Manufacturing in Practice" Procedia Engineering 182 ( 2017 )

[19] Daniela Santana Lambert Marzagão "Critical success factors for Six Sigma project" International Journal of Project Management 34 (2016)

[20] Adan Valles1, Jaime Sanchez "Implementation of Six Sigma in a Manufacturing Process: A Case Study" International Journal of Industrial Engineering, 16(3), 171-181, 2014.

[21] Ayadi Youssef "Contribution To The Optimization Of Strategy Of

Maintenance By Lean Six Sigma" Physics Procedia, Elsevier 55 ( 2014 )

[22] Halvor Holtskog "Continuous Improvement beyond the Lean understanding" Procedia CIRP, Elsevier 7 ( 2013 )

[23] Hikmet Erbiyika and Muhsine Sarua "Six Sigma Implementations in Supply Chain: An Application for an Automotive Subsidiary Industry in Bursa in Turkey" Procedia - Social and Behavioural Sciences, Elsevier 195 ( 2015 )

[24] Monika Smętkowska "Using Six Sigma DMAIC to improve the quality of the production process: a case study" Procedia - Social and Behavioural Sciences 238 ( 2018 )

[25] Hassan Soltana and Sherif Mostaf "Lean and agile performance framework for manufacturing Enterprises" Procedia Manufacturing, Elsevier 2 ( 2015 )

\section{BOOKS}

[1] D.C Montgomery "Introduction To Statistical Quality Control,6 $6^{\text {th }}$ Edition"

[2] M.P GROOVER "Fundamentals of modern manufacturing, Materials, Processes and Systems, 4th Edition"

[3] Myer Kurtz "Handbook of Material Selection"

[4] S. Kalpakjian "Manufacturing Engineering and Technology, 6th Edition"

[5] D.H Stamatis "Failure Mode Effect Analysis 
From Theory To Execution, 2nd Edition"

[6] O.P KHANNA "A text book of Production Technology" 1st Edition

\section{WEBSITES}

[1] Indian Railways http://www.indianrailways.gov.in/

[2] Lean Manufacturing Tools http://leanmanufacturingtools.org

[3] Quality-One International https://qualityone.com/pfmea/

[4] $5 \mathrm{~S} \quad$ Implementation https://leanconstructionblog.com/

[5] Concept Business Excellence https://www.sixsigmaconcept.com/

\section{Cite this article as :}

Tafadzwa Majoni, Prof. Prashant Tomar, "Lean Six Sigma for Quality and Performance Improvement of POH Process of Wagon Wheel CTRB", International Journal of Scientific Research in Science and Technology (IJSRST), Online ISSN : 2395-602X, Print ISSN : 2395-6011, Volume 6 Issue 2, pp. 471-486, March-April 2019. Available at doi : https://doi.org/10.32628/IJSRST196259 Journal URL : http://ijsrst.com/IJSRST196259 